\title{
KONTRIBUSI USAHATANI PEMBIBITAN CABAI RAWIT TERHADAP PENDAPATAN RUMAH TANGGA KELOMPOK TANI PERDI DI DESA DILEM KECAMATAN KEPANJEN KABUPATEN MALANG
}

\author{
Zainol Arifin ${ }^{1 *}$ \\ 1)* Program Studi Agribisnis Fakultas Pertanian Universitas Tribhuwana Tunggadewi \\ email : $\underline{\text { dr.zainolarifin@gmail.com }}{ }^{1 *}$
}

\begin{abstract}
Abstrak
Prospek usahatani pembibitan sayuran cabai, di desa Dilem kecamatan Kepanjen cukup besar, namun belum diketahui tingkat kelayakannya. Petani umumnya sudah mengadakan perhitungan ekonomi, namun tidak dilakukan secara tertulis dan masih banyak petani yang belum menghitung berapa tingkat pendapatan usahatani yang diusahakannya. Sebagai dasar untuk mengembangkan suatu usahatani, diperlukan suatu sistem informasi untuk mengetahui total biaya, produktivitas bibit, pendapatan dan kelayakan dari usahatani khususnya pembibitan cabai rawit. Tujuan penelitian ini adalah untuk mengetahui faktor pendorong usahatani pembibitan cabai rawit terhadap pendapatan rumah tangga pada kelompok tani Perdi desa Dilem kecamatan Kepanjen kabupaten Malang dan untuk mengetahui kontribusi usahatani pembibitan cabai rawit terhadap pendapatan rumah tangga pada kelompok tani Perdi desa Dilem kecamatan Kepanjen kabupaten Malang. Metode penentuan sampel yang digunakan pada penelitian ini adalah metode teknik sengaja (purposive sampling). Peneliti mengambil secara sengaja sampel semua anggota kelompok tani berjumlah 36 orang. Faktor yang mendorong anggota kelompok tani pembibitan cabai rawit di desa Dilem kecamatan Kepanjen kabupaten Malang untuk menjalankan usahatani pembibitan cabai rawit, antara lain : banyak tenaga kerja yang tersedia di desa Dilem, pemanfaatan sarana produksi sebagai alat bantu produksi, dukungan dari perangkat atau Pemerintah desa, karakteristik atau kearifan lokal yang dimiliki oleh penduduk desa Dilem, tingginya permintaan bibit tanaman cabai, akses lokasi yang mudah dijangkau dan ketersediaan atau kepemilikan lahan. Besarnya kontribusi dari usahatani pembibitan cabai rawit terhadap total pendapatan rumah tangga di desa Dilem adalah sebesar 58,93\%. Hal ini menunjukan bahwa usahatani pembibitan cabai rawit merupakan sumber pendapatan yang memberikan kontribusi yang cukup besar, jadi usahatani ini sangat cocok dikembangkan di desa Dilem kecamatan Kepanjen kabupaten Malang.
\end{abstract}




\section{PENDAHULUAN}

Peran sektor pertanian dalam pembangunan Indonesia diarahkan untuk meningkatkan produksi pertanian guna memenuhi kebutuhan pangan dan industri dalam negeri, untuk meningkatkan ekspor, sumber pendapatan petani, membuka

kesempatan kerja dan mendorong pemerataan kesempatan berusaha. Peran strategis sektor pertanian bisa digambarkan dalam kontribusi sektor pertanian yang dalam kegiatannya berperan sebagai penyedia bahan pangan, kemudian bahan baku industri, dan juga sebagai sumber utama pendapatan rumah tangga pedesaan.

Pertanian merupakan sektor ekonomi yang mempunyai peran penting di Indonesia. Sektor pertanian sangat strategis sebagai basis ekonomi rakyat di pedesaan, menguasai hajat hidup sebagian besar penduduk, menyerap tenaga kerja dan memberikan kontribusi sebesar 12,9\%. Sektor pertanian juga berperan besar dalam penyediaan pangan untuk mewujudkan ketahanan pangan dan bahan mentah yang dibutuhkan oleh suatu negara. Kebutuhan produk-produk pertanian semakin meningkat seiring dengan peningkatan jumlah penduduk dan sektor ini juga merupakan sumber pekerjaan dan pendapatan bagi sebagian besar penduduk negara berkembang seperti di Indonesia.

Berdasarkan data yang diambil dari Badan Pusat Statistik Kabupaten Malang jumlah produksi cabai rawit dari 2016 dan 2017 sejumlah 25.831 ton dan 43.253 ton yang mengalami peningkatan yang signifikan. (BPS, 2018). Karena peningkatan produktivitas petani dan usaha pertanian merupakan sesuatu yang penting ke depan. Masyarakat dunia dalam waktu tidak lama lagi membutuhkan hasil pertanian yang banyak, berkualitas tinggi dan dengan harga yang bersaing. Pembangunan pertanian Indonesia telah dilaksanakan secara bertahap dan berkelanjutan dengan harapan dapat meningkatkan produksi pertanian semaksimal mungkin sehingga dapat meningkatkan pendapatan petani dalam mencapai kesejahteraan, peningkatan prosuksi pangan. Kesejahteraan petani merupakan arah dan tujuan pembangunan pertanian.

Tingkat kebutuhan masyarakat Indonesia berdasarkan data statistik melalui survey Sosial Ekonomi Nasional (SUSENAS) yang dilakukan Badan Pusat Statistik mengalami peningkatan konsumsi dari tahun ke tahun ini dapat menjadi peluang besar bagi para petani membudidayakan khususnya dibidang sayuran seperti: Cabai, terung dan tomat. Untuk mengurangi tingkat efisiensi penggunaan lahan sebagai media tanam budidaya sayur maka salah satu peluang usahanya adalah usaha persemaian bibit sayur untuk memenuhi kebutuhan petani sayur yang kian meningkat setiap tahunnya. Tingkat efisiensi dari sudut pandang luas lahan yang diperlukan lebih sempit dibandingkan membudidayakannya di sawah atau di tegalan. Dan biaya saprodi yang digukanakan pasti lebih sedikit. Peluang bisnis usahatani persemaian bibit sayur terbuka lebar dengan tingkat konsumsi masyarakat yang setiap tahunnya meningkat. Selain ditinjau dari potensi yang dimilikinya, maka diperlukan juga suatu informasi mengenai kelayakan finansial dari suatu usahatani. Kelayakan finansial bertujuan untuk mengetahui apakah usahatani yang ingin dilakukan termasuk usaha yang layak untuk diusahakan atau tidak. Jika usahatani layak untuk diusahakan, maka usaha dapat terus dilanjukan dan dikembangkan, hal tersebut diharapkan akan memberikan dampak positif berupa manfaat yang akan diterima, seperti adanya peningkatan pendapatan dari para pelaku usahatani tersebut.

Tanaman hortikultura, utamanya sayuran merupakan komoditi pertanian yang memiliki harga cukup tinggi di pasaran. Salah satu komoditi sayur yang sangat dibutuhkan oleh hampir semua orang dari berbagai lapisan masyarakat, adalah cabai rawit, sehingga tidak mengherankan bila volume peredaran di 
pasaran dalam skala besar (Santika, 2005). Lebih lanjut Setiadi (2009) menyatakan cabai rawit merupakan bahan masakan sehingga cabai rawit sangat diperlukan oleh sebagian besar ibu rumah tangga sebagai pelengkap bumbu dapur.

Pasar-pasar tradisional di Jakarta membutuhkan cabai rawit setiap harinya sebanyak 75 ton, dan di pasar tradisional Bandung membutuhkan 32 ton per hari.

Cabai rawit (Capsicum frutescens L.) merupakan salah satu jenis sayuran penting yang dibudidayakan secara komersial di Negara tropis. Tercatat berbagai spesies cabai yang telah didomestikasi, namun hanya Capsicum annum $L$. dan Capsicum frutescens $L$. yang memiliki potensi ekonomis (Sulandari, 2004). Cabai rawit (Capsicum frutescens L.) merupakan salah satu tanaman hortikultura dari jenis sayuran yang memiliki buah kecil dengan rasa yang pedas. Ali (2015), produksi tanaman cabai rawit dari tahun ke tahun terus meningkat, 2009 produksinya sebesar 591.294 ton, sedangkan pada 2010 produksinya sebesar 521.704 ton.

Pembibitan pada biji cabai rawit harus disemaikan lebih dulu sebelum ditanam. Untuk mempercepat pertumbuhannya, biji cabai sebaiknya direndam dahulu dalam air selama 24 jam sebelum ditanam. Perlu diperhatikan bahwa biji cabai yang baik adalah biji yang betul-betul masak dan kering. Cara menyemai biji cabai sangatlah beragam, ada yang menggunakan kotak pesemaian, pesemaian di lapangan, kantung plastik atau kantung dari daun kelapa, enau, pisang dll. Tanah yang digunakan untuk pesemaian menggunakan tanah yang subur dan bebas dari gangguan hama dan penyakit.

Persemaian

sebaiknya

menggunakan atap dari daun rebu, daun kelapa maupun daunan lainnya agar suasana menjadi lebih lembab supaya tanaman tidak terkena sinar matahari langsung. Atap dapat dibuka atau ditutup menurut keperluan saja. Dipagi sampai jam 10.00 atap dibuka, kemudian ketika cuaca panas lebih dari jam 10.00 atap dapat ditutup kembali. Kalau persemaian dibuat dalam kotak kecil dapat dimasukkan dalam rumah.

Peluang usaha budidaya cabai rawit menjadi sangat mengutungkan karena nilai jual cabai rawit yang bagus membuat untung jika membudidayakan cabai rawit. Untuk cara membudidayakan cabai rawit memanglah tidak sulit dilakukan dengan lahan yang sempit. Sekarang ini memang banyak orang yang memanfaatkan luas lahan yang sempit dengan cara penanaman hidroponik. Memang melakukan bisnis budidaya cabai rawit ini sangatlah mudah.

Desa Dilem kecamatan Kepanjen kabupaten Malang banyak petani-petani yang memiliki usahatani persemaian tanaman sayur diantaranya: cabai rawit, cabai merah, tomat, terung dan aneka jenis bibit kayu. Usahatani persemaian berbagai jenis sayuran, jika dilihat dari prosesnya usahatani persemaian bibit sayur sangat sederhana membutuhkan ketelatenan dan keterampilan untuk menciptakan bibit berkualitas. Modal biaya yang digunakan lebih sedikit dan luas lahan yang diperlukan lebih sempit bisa dilakukan di perkarangan rumah.

Pentingnya penelitian ini

agar dapat mendalami tentang ilmu kontribusi usahatani serta dapat mengetahui besarnya kontribusi yang didapat.

Prospek usahatani pembibitan sayuran cabai, terung dan tomat di desa Dilem kecamatan Kepanjen cukup besar, namun belum diketahui tingkat kelayakannya. Orientasi petani di daerah penelitian masih bersifat memenuhi kebutuhan pangan keluarga. Petani umumnya sudah mengadakan perhitungan ekonomi, namun tidak dilakukan secara tertulis dan masih banyak petani yang belum menghitung berapa tingkat pendapatan usahatani yang diusahakannya. Sebagai dasar untuk mengembangkan suatu usahatani, diperlukan suatu sistem informasi untuk mengetahui total biaya, produktivitas bibit, pendapatan dan 
kelayakan dari usahatani khususnya pembibitan cabai rawit. Penelitian ini untuk mengetahui total biaya, produktivitas, penerimaan, pendapatan dan kelayakan dalam satu kali periode tanam. Berdasarkan latar belakang tersebut, maka perlu dilakukan penelitian tentang "Kontribusi Usahatani Pembibitan Cabai Rawit Terhadap Pendapatan Rumah Tangga Kelompok Tani Perdi Di Desa Dilem Kecamatan Kepanjen Kabupaten Malang"

Tujuan dalam penelitian ini adalah:

1. Untuk mengetahui faktor pendorong dari usahatani pembibitan cabai rawit terhadap pendapatan rumah tangga pada kelompok tani perdi desa Dilem kecamatan Kepanjen kabupaten Malang.

2. Untuk mengetahui kontribusi usahatani pembibitan cabai rawit terhadap pendapatan rumah tangga pada kelompok tani perdi desa Dilem kecamatan Kepanjen kabupaten Malang.

\section{METODE PENELITIAN}

Lokasi yang dipilih sebagai tempat penelitian yaitu kelompoktani Perdi desa Dilem kecamatan Kepanjen kabupaten Malang. Pemilihan tempat penelitian ini dengan alasan bahwa kelompoktani Perdi desa Dilem memiliki kegiatan usaha pembibitan cabai rawit (Capsicum frutescens l.) yang dilakukan oleh para anggota kelompok tani. Waktu penelitian dimulai dari bulan Juli 2019 hingga bulan Agustus 2019. Data yang digunakan dalam penelitian ini terdiri dari data primer dan data sekunder. Metode penentuan sampel yang digunakan pada penelitian ini adalah metode teknik sengaja (purposive sampling). Metode purposive sampling menurut Sugiono (2012) adalah teknik penentuan sampel dengan pertimbangan khusus. Pada penelitian ini, peneliti mengambil secara sengaja sampel semua anggota kelompok tani berjumlah 36 orang. Teknik analisa data yang digunakan dalam penelitian ini adalah sebagai berikut: analisis deskriptip persentase, analisis ini digunakan untuk mengetahui kontribusi usahatani pembibitan cabai rawit terhadap pendapatan rumah tangga kelompok tani Perdi dalam

satuan persen. Kontribusi adalah sumbangan yang dapat diberikan oleh suatu hal terhadap hal lain. Data yang diperoleh dianalisis tanpa uji statistik dengan menghitung jumlah uang yang diperoleh dari suatu kegiatan usahatani pembibitan cabai rawit dan pendapatan total rumah tangga petani dikali seratus persen.

Untuk mengetahui kontribusi usahatani pembibitan cabai terhadap pendapatan rumah tangga kelompok tani perdi digunakan rumus persentase sebagai berikut: Kontribusi $(\%)=$ (Pendapatan usahatani pembibitan cabai rawit)/(pendapatan total rumah tangga) $\mathrm{x}$ $100 \%$

Analisis usahatani dilakukan untuk mengetahui seberapa besar penerimaan atau pendapatan kotor dan biaya-biaya yang dikeluarkan petani untuk usahatani pembibitan cabai rawit serta keuntungan yang diperoleh petani dari hasil usahatani tersebut. Adapun rumus analisis pendapatan usahatani, yaitu:

$\mathrm{I}=\mathrm{TR}-\mathrm{TC}$

Dimana:

$\mathrm{I}=$ Income (pendapatan)

$\mathrm{TR}=$ Total Revenue (penerimaan) $\rightarrow$ Jumlah produksi $\mathrm{x}$ harga

$\mathrm{TC}=$ Total Cost (biaya) $\rightarrow T V C+T F C$

\section{HASIL DAN PEMBAHASAN}

\section{Faktor Pendukung Terkait Usahatani Pembibitan Cabai Rawit}

Usahatani pembibitan cabai rawit merupakan salah satu usaha dibidang pertanian yang cukup menjanjikan. Menjalankan usahatani pembibitan cabai rawit tersebut lebih banyak memberikan sumbangan terhadap pendapatan rumah tangga untuk memenuhi kebutuhan dan 
menjaga kelangsungan hidup mereka. Namun tidak semua anggota kelompok tani Perdi mampu mendapatkan keuntungan yang besar serta mampu mengembangkan usahatani pembibitan cabai rawit tersebut.

Berdasarkan hasil penelitian di desa Dilem kecamatan Kepanjen dapat diketahui faktor pendorong atau pendukung usahatani pembibitan cabai rawit terhadap pendapatan rumah tangga adalah sebagai berikut: 
a. Banyak tenaga kerja yang tersedia di desa Dilem

Pemanfaata

b. $\mathrm{n}$ sarana produksi sebagai alat bantu produksi

c. Dukungan dari perangkat atau Pemerintah desa

d. Karakteristik atau kearifan lokal yang dimiliki oleh penduduk desa Dilem

e. Tingginya permintaan benih tanaman cabai

Tabel 1. Biaya Produksi Dari Usahatani Pembibitan Cabai Rawit

\begin{tabular}{|c|c|c|c|}
\hline \multirow{2}{*}{ No } & Biaya Produksi & \multirow{2}{*}{ Frekuensi } & Persentase \\
\cline { 3 - 4 } & $(\mathbf{R p})$ & & $(\boldsymbol{\%})$ \\
\hline 1 & $<500.000$ & - & - \\
\hline 2 & $500.000-1.000 .000$ & 31 & 86,11 \\
\hline 3 & $>1.000 .000$ & 5 & 13,89 \\
\hline & Jumlah & $\mathbf{3 6}$ & $\mathbf{1 0 0}$ \\
\hline
\end{tabular}

Sumber: Data Primer diolah tahun 2019

Tabel 1 di atas menunjukan bahwa biaya produksi dari usahatani pembibitan cabai rawit adalah sebesar $86,11 \%$ dengan biaya produksi Rp 500.000 - Rp 1.000 .000 ada 31 responden dan sebesar $13,89 \%$ dengan biaya produksi > Rp 1.000 .000 ada 5 responden. Berdasarkan data di atas dapat disimpulkan bahwa biaya produksi terbanyak yang dikeluarkan dari usahatani pembibitan cabai rawit adalah antara $\mathrm{Rp}$ 500.000 - Rp 1.000.000 yaitu sebanyak 31 responden. f. Akses lokasi yang mudah dijangkau

g. Ketersediaan atau kepemilikan lahan

\section{Biaya Produksi Usahatani Pembibitan}

\section{Cabai Rawit}

Biaya produksi dari usahatani yang dikeluarkan pada saat pelaksanaan usahatani pembibitan cabai rawit dilakukan. Biaya produksi dari usahatani pembibitan cabai rawit dapat dilihat dalam tabel 1 berikut: pembibitan cabai rawit adalah biaya 
pertanian selama 1 bulan dihitung dengan cara mencari pendapatan pertanian pertahun yang dihitung berdasarkan banyaknya panen selama setahun dikurangi biaya produksinya.

Pendapatan yang diperoleh dari pertanian selain pertanian pembibitan cabai rawit dapat dilihat dalam tabel 2 berikut ini: 
Tabel 2. Pendapatan Dari Usaha Pertanian

\begin{tabular}{|c|c|c|c|}
\hline \multirow{2}{*}{ No } & Pendapatan & Frekuensi & Persentase \\
\cline { 3 - 4 } & $(\mathbf{R p})$ & & $\mathbf{( \% )}$ \\
\hline 1 & $\leq 1.000 .000$ & 13 & 36,11 \\
\hline 2 & $>1.000 .000-<1.500 .000$ & 13 & 36,11 \\
\hline 3 & $\geq 1.500 .000$ & 10 & 27,78 \\
\hline & Jumlah & $\mathbf{3 6}$ & $\mathbf{1 0 0}$ \\
\hline
\end{tabular}

Sumber: Data Primer diolah tahun 2019

Tabel 2 di atas menunjukan bahwa pendapatan dari usaha pertanian dalam kurun waktu satu bulan adalah sebesar 36,11\% pendapatan responden di bawah $\leq$ Rp 1.000.000, yang berarti terdapat

13 responden memperoleh pendapatan lebih kecil atau sama dengan Rp 1.000.000, sebesar $36,11 \%$ pendapatan responden antara > Rp 1.000.000 - < Rp 1.500.000, yang berarti terdapat 13 responden memperoleh pendapatan berkisar antara di atas $\mathrm{Rp}$ 1.000.000 hingga di bawah $\mathrm{Rp}$ 1.500.000 dan

sebesar $27,78 \%$ pendapatan responden $\geq \mathrm{Rp} 1.500 .000$, yang berarti terdapat 10 responden memperoleh pendapatan di atas atau sama dengan Rp 1.500.000.

Berdasarkan data di atas dapat disimpulkan bahwa secara umum pendapatan berasal dari pertanian selain pembibitan cabai rawit dan hal ini menunjukkan juga bahwa hasil panen masih dipergunakan untuk memenuhi kebutuhan pribadi dan dijual untuk membeli kebutuhan lainnya guna kelangsungan hidup responden.

Kegiatan dari usahatani di daerah penelitian ini dilakukan petani untuk keperluan menambah pendapatan yang diterima sehingga dapat memenuhi kebutuhan dalam rumah tangga.

2. Pendapatan dari Luar Usaha Tani Pembenihan Bibit Cabai Rawit Non Pertanian

Pendapatan dari luar usahatani pembibitan cabai rawit non pertanian adalah pendapatan yang diperoleh responden selain berusaha sebagai petani yaitu pendapatan yang diperoleh dari luar usaha pembibitan cabai rawit, seperti bekerja sebagai buruh dan pedagang dalam kurun waktu 1 bulan untuk jelasnya dilihat dalam tabel 3 berikut ini: 
Tabel 3. Pendapatan Dari Luar Usahatani Pembibitan Cabai Rawit Non Pertanian

\begin{tabular}{|c|c|c|c|}
\hline \multirow{2}{*}{ No } & Pendapatan & Frekuensi & Persentase \\
\cline { 3 - 4 } & $(\mathbf{R p})$ & & $\mathbf{( \% )}$ \\
\hline 1 & Tanpa penghasilan & 17 & 47,22 \\
\hline 2 & $<1.500 .000$ & 11 & 30,56 \\
\hline 3 & $\geq 1.500 .000$ & 8 & 22,22 \\
\hline & Jumlah & $\mathbf{3 6}$ & $\mathbf{1 0 0}$ \\
\hline
\end{tabular}

Sumber: Data Primer diolah tahun 2019 
Tabel 3 di atas menunjukan

bahwa pendapatan dari luar usahatani pembibitan cabai non pertanian dalam kurun waktu satu 47,22

bulan adalah sebesar \% penghasila

responden tanpa $\mathrm{n}$ dari usaha non pertanian, yang berarti

terdapat 17 responden tidak $\begin{array}{lr} & 30,56 \\ \text { berpenghasilan, } & \text { sebesar }\end{array}$ responden dengan pendapatan $<\mathrm{Rp}$ 1.500 .000 , yang berarti terdapat 11

responden dengan penghasilan di bawah Rp 1.500.000 dan sebesar

$22,22 \%$ responden dengan pendapatan $\geq R p 1.500 .000$, yang berarti 8 responden dengan penghasilan di atas atau sama dengan Rp1.500.000.

Tingginy a persentase responden dengan 0 pendapatan atau tanpa penghasilan dari usaha dikarenaka non pertanian ini sebagian besar warga responden sebaga

bermata pencaharian $\mathrm{i}$ petani baik pekerjaan pokok maupun pekerjaan tambahan.

3. Pendapatan dari Usahatani Pembibitan Cabai

Rawit

Pendapatan usahatani rawi

pembibitan cabai $\mathrm{t}$ adalah

pendapatan yang diperoleh responden dari usahatani pembibitan

cabai rawit per bulan dan dinyatakan

dalam rupiah. Pendapatan ini merupakan pendapatan bersih usahatan caba i pembibitan i rawit yang berasal dari penerimaan hasil

penjualan. Hasil produksi dikurangi dengan biaya produksi selama sebulan dalam satuan rupiah.

Pendapatan dari usahatani pembibitan cabai rawit dapat dilihat dalam tabel 4 berikut: 
Tabel 4. Pendapatan Usahatani Pembibitan Cabai Rawit

\begin{tabular}{|c|c|c|c|}
\hline \multirow{2}{*}{ No } & Pendapatan & Frekuensi & Persentase \\
\cline { 3 - 4 } & $(\mathbf{R p})$ & & $(\boldsymbol{\%})$ \\
\hline 1 & $<2.500 .000$ & 9 & 25 \\
\hline 2 & $2.500 .000-3.000 .000$ & 17 & 47,22 \\
\hline 3 & $>3.000 .000$ & 10 & 27,78 \\
\hline & $\begin{array}{l}\text { Jumla } \\
\text { h }\end{array}$ & $\mathbf{3 6}$ & $\mathbf{1 0 0}$ \\
\hline
\end{tabular}

Sumber: Data Primer diolah tahun 2019

Tabel 4 di atas menunjukan bahwa pendapatanresponden dengan pendapatan di atas Rp dari usahatani pembibitan cabai rawit dalam3.000.000. Sehingga dapat disimpulkan bahwa kurun waktu satu bulan adalah sebesar 25\% pendapatan responden terbesar adalah diantara pendapatan responden di bawah Rp 2.500.000,Rp 2.500.000 - Rp 3.000.000 yaitu 17 yang berarti terdapat 9 responden denganresponden.

penghasilan di bawah Rp 2.500.000, sebesar Perbandingan dari ketiga pendapatan $47,22 \%$ pendapatan responden antara Rpyang berasal dari usaha pertanian, pendapatan 2.500.000 - Rp 3.000.000, yang berarti 17dari luar usahatani pembibitan cabai rawit dan responden dengan penghasilan berkisar antarapendapatan dari usahatani pembibitan cabai Rp 2.500.000 hingga Rp 3.000.000 danrawit menunjukan bahwa cukup besarnya sebesar $27,78 \%$ pendapatan responden lebihkontribusi yang diberikan pada pendapatan dari $\mathrm{Rp}$ 3.000.000, yang berarti terdapat 10petani.

\section{Total Pendapatan Rumah Tangga}

Total pendapatan rumah tangga responden dalam penelitian ini adalah seluruh pendapatan yang diterima oleh responden dalam kurun waktu satu bulan

Tabel 5. Total Pendapatan Rumah Tangga usahatani pembibitan cabai rawit, pendapatan dari luar pembibitan cabai rawit non pertanian dan pendapatan dari pertanian dapat dilihat dari tabel 5 berikut ini: dan dinyatakan dalam rupiah. Total pendapatan rumah tangga merupakan hasil seluruh pendapatan bersih dari pendapatan 
pendapatan rumah tangga diketahui maka

\begin{tabular}{|c|c|c}
\hline No & Pendapatan & Fre \\
& $(\mathbf{R p})$ & \\
\hline 1 & $\leq 4.000 .000$ & \\
\hline 2 & $>4.000 .000-6.000 .000$ & \\
\hline 3 & $>6.000 .000$ & \\
\hline \multicolumn{2}{|c|}{ Jumlah } & \\
\hline
\end{tabular}

Sumber: Data Primer diolah tahun 2019

Pendapatan dari usaha pertanian meliputi usaha padi dan usaha sayuran, pendapatan dari luar usahatani pembibitan cabai rawit dari berdagang atau berternak, dan pendapatan dari usahatani pembibitan cabai rawit yang ditambah sehingga dapat diketahui besarnya total pendapatan yang diterima petani di daerah penelitian.

Berdasarkan tabel 5 menunjukan total pendapatan rumah tangga responden adalah sebesar $13,89 \%$ responden dengan pendapatan total $\leq \mathrm{Rp} 4.000 .000$, yang berarti terdapat 5 responden memperoleh total pendapatan rumah tangga lebih kecil atau sama dengan Rp 4.000.000, sebesar $72,22 \%$ responden dengan pendapatan total antara Rp 4.000.000 - Rp 6.000.000, yang berarti terdapat 26 responden memperoleh total pendapatan rumah tangga di atas $\mathrm{Rp} 4.000 .000$ hingga $\mathrm{Rp}$ 6.000 .000 dan $13,89 \%$ responden dengan pendapatan total > Rp 6.000.000, yang berarti terdapat 5 responden memperoleh total pendapatan rumah tangga di atas $\mathrm{Rp}$ 6.000.000.

Berdasarkan data di atas dapat disimpulkan bahwa total pendapatan terbanyak Rp 4.000.000 - Rp 6.000.000 yaitu sebanyak 26 responden yang berasal dari pendapatan pertanian luar usahatani pembibitan cabai rawit dan usahatani pembibitan cabai rawit dan juga seluruh pendapatan anggota rumah tangga petani yang dijumlahkan. Setelah total perhitungan kontribusirsenarise usahatani

Frekfuensibitan cabal rawit terhadap

pendapatan rumah tangga\% dapat dihitung dengan menggunakan analisis statistik

secterhana. $\quad 13,89$

\begin{tabular}{l|ll} 
Kontribus: & Oari Usahatani Pembibitan \\
Cabai & Rawit Terhadap Total
\end{tabular} Pendapatan-Rumah-Tangera-Responden Kontribusi yang dtrmaksud dalam penelitian ini adalah sumbangan dari

36ahatani pembibitan cd8\&1 rawit yang dilakukan di daerah penelitian sebanyak 36 anggota kelompok tani yang berprofesi sebagai petani pembibitan cabai rawit. Usahatani pembibitan cabai rawit di desa Dilem diusahakan oleh anggota kelompok tani untuk memperoleh pendapatan. Selain dari usahatani pembibitan cabai rawit para anggota kelompok tani di desa Dilem juga memperoleh pendapatan dari usaha selain usahatani pembibitan cabai rawit. Pendapatan rumah tangga dari usaha lain diperoleh dari hasil bertani sayur, bertani jagung, bertani padi, berdagang, beternak atau lain sebagainya baik yang dikerjakan kepala keluarga maupun anggota keluarga. Pendapatan total rumah tangga disini dapat dihitung dari pendapatan usahatani pembibitan cabai rawit, pendapatan pertanian dan pendapatan diluar usahatani pembibitan cabai rawit non pertanian. I Untuk perhitungan kontribusi dari usahatani pembibitan cabai rawit terhadap pendapatan total menggunakan rumus: Kontribusi $(\%)=($ Pendapatan usahatani pembibitan cabai rawit)/(pendapatan total rumah tangga) $x 100 \%$

Untuk lebih jelas, besarnya kontribusi usahatani pembibitan cabai rawit dapat dilihat dalam tabel 6 berikut ini: 
Tabel 6. Kontribusi Usahatani Pembibitan Cabai Rawit Terhadap Pendapatan Rumah Tangga

\begin{tabular}{|l|c|c|}
\hline \multicolumn{1}{|c|}{ Sumber Pendapatan } & Jumlah & Persentase \\
\cline { 3 - 3 } & Pendapatan (Rp) & $(\boldsymbol{\%})$ \\
\hline Usaha Tani Pembenihan Bibit Cabai & 107.200 .000 & 58,93 \\
Rawit & 50.360 .000 & 27,68 \\
\hline Usaha Tani Non Pembenihan Bibit & & 13,93 \\
\hline Uabai Rawit & 25.350 .000 & $\mathbf{1 0 0}$ \\
\hline Jumlah Non Pertanian & 181.910 .000 & \\
\hline
\end{tabular}


Sumber: Data Primer diolah tahun 2019

Berdasarkan tabel 6 di atas dapat disimpulkan bahwa kontribusi usahatani pembibitan cabai rawit terhadap pendapatan total rumah tangga adalah sebesar 58,93\%, artinya mayoritas masyarakat dalam berusahatani pembibitan cabai rawit masih dominan untuk menghasilkan pendapatan. Hal ini menunjukan lebih dari separuh pendapatan rumah tangga anggota kelompok tani berasal dari usahatani pembibitan cabai rawit. Usahatani pembibitan cabai rawit memberikan kontribusi cukup besar terhadap pendapatan total rumah tangga kelompok tani dan pendapatan tersebut digunakan untuk memenuhi kebutuhan keluarga , seperti biaya makan sehari-hari, biaya sekolah anak dan lain sebagainya.

\section{Pembahasan Hasil Penelitian}

Berdasarkan hasil

penelitian

kontribusi usahatani pembibitan cabai rawit terhadap pendapatan rumah tangga kelompok tani perdi di desa Dilem kecamatan Kepanjen kabupaten Malang diperoleh keterangan sebagian besar petani pembibitan cabai rawit di desa Dilem kecamatan Kepanjen kabupaten Malang hasil dari usahatani tersebut mampu mencukupi kebutuhan keluarga.

Hasil penelitian menjelaskan usahatani pembibitan cabai rawit merupakan usaha yang mempunyai keuntungan lebih besar dibandingkan dengan tanaman lain.

Mayoritas usahatani pembibitan cabai rawit yang dijalankan responden di desa Dilem ini sudah berjalan sangat lama dan usaha ini dilaksanakan secara turuntemurun.

Dari beberapa wawancara bersama responden menunjukan bahwa usahatani pembibitan cabai rawit di desa Dilem kecamatan Kepanjen kabupaten Malang ini dijalankan secara turun-temurun yang diwariskan oleh orang tua, para petani belajar usahatani ini berdasarkan pengamatan mereka terhadap usaha yang orang tua mereka jalankan.

Para petani pembibitan cabai rawit di desa Dilem tertarik untuk menjalankan usaha ini dengan alasan usahatani tersebut lebih banyak memberikan sumbangan terhadap pendapatan rumah tangga untuk memenuhi kebutuhan dan menjaga kelangsungan hidup mereka dibandingkan dengan kegiatannya dibidang selain usahatani pembibitan cabai rawit seperti pertanian padi dan sayuran. Hal ini berdasarkan wawancara yang diterima peneliti saat melakukan penelitian.

Berdasarkan hasil wawancara antara peneliti dan responden ketika peneliti mengambil data, usahatani pembibitan cabai bukanlah pekerjaan pokok, melainkan usaha tambahan yang mereka lakukan. Meskipun usaha tambahan para anggaota kelompok tani beranggapan bahwa usaha pembibitan cabai rawit ini lebih banyak memberikan sumbangan terhadap pendapatan rumah tangga petani untuk memenuhi kebutuhan dan menjaga kelangsungan hidup mereka dibandingkan dengan kegiatannya dibidang selain pembibitan cabai rawit.

Dari hasil penelitian yang tercantum dalam tabel 6 diketahui bahwa usahatani pembibitan cabai rawit mempunyai kontribusi sebesar 58,93\% terhadap pendapatan rumah tangga kelompok tani perdi di desa Dilem kecamatan Kepanjen kabupaten Malang. Hasil tersebut diperoleh dari rumus kontribusi yaitu total pendapatan dari usahatani pembibitan cabai rawit dibagi total pendapatan rumah tangga dikalikan seratus persen.

Usahatani pembibitan cabai rawit merupakan usaha sambilan yang bisa dijalankan kapan saja. Meskipun dibilang sebagai usaha sambilan, tapi usahatani pembibitan cabai rawit tersebut merupakan usaha yang cukup menjanjikan untuk 
menjaga kelangsungan hidup petani. Hal ini bisa dilihat dari besarnya kontribusi pendapatannya lebih besar dari usaha lain, yaitu kontribusinya sebesar 58,93\%. Dari hasil usahatani pembibitan cabai mampu digunakan untuk memenuhi kebutuhan keluarga seperti biaya makan sehari-hari, biaya sekolah anak dan biaya lain-lain.

Selain dari usahatani pembibitan cabai rawit petani juga memperoleh kontribusi sebesar $41,61 \%$ yang berasal dari usaha lain, misalnya dari usaha pertanian selain usahatani pembibitan cabai rawit yang memberikan kontribusi sebesar $27,68 \%$ seperti usahatani padi, usahatani sayuran dan usahatani jagung. Dan 13,93\% kontribusinya berasal dari sumbangan pendapatan dari non usahatani pembibitan cabai rawit non pertanian, usaha non pertanian yang dijalankan anggota kelompok tani di desa Dilem berupa pegawai maupun pedagang.

Berdasarkan penjelasan di atas dapat disimpulkan bahwa usahatani pembibitan cabai rawit memberikan kontribusi lebih dari separuhnya dibandingkan dengan usaha lain yaitu sebesar 58,93\%, jadi usahatani ini sangat cocok untuk dikembangkan di desa penelitian yaitu desa Dilem kecamatan Kepanjen kabupaten Malang.

\section{KESIMPULAN}

1. Faktor yang mendorong anggota kelompoktani pembibitan cabai rawit di desa Dilem kecamatan Kepanjen kabupaten Malang untuk menjalankan usaha tani pembenihan bibit cabai rawit adalah: d. Karakteristik atau kearifan lokal yang dimiliki oleh penduduk desa Dilem

e. Tingginya permintaan benih tanaman cabai

f. Akses lokasi yang mudah dijangkau

g. Ketersediaan atau kepemilikan lahan

2. Besarnya kontribusi dari usahatani pembibitan cabai rawit terhadap total pendapatan rumah tangga di desa Dilem adalah sebesar 58,93\%. Hal ini menunjukan bahwa usahatani pembibitan cabai rawit merupakan sumber pendapatan yang memberikan kontribusi yang cukup besar, jadi usahatani ini sangat cocok dikembangkan di desa Dilem kecamatan Kepanjen kabupaten Malang.

\section{DAFTAR PUSTAKA}

Anonymous $^{1}$. 2020. Bab I Pendahuluan. http://eprints.umm.ac.id/39811/2/BAB\%20I.p df. diakses 22 April 2020.

2. 2020. Bab I Pendahuluan.

https://docplayer.info/47552510-I-

pendahuluan-cabai-capsicum-annum-1merupakan-salah-satu-jenis-sayuranpenting-yang.html. diakses pada 22 April 2020 .

3. 2020. Bab I Pendahuluan.

http://siat.ung.ac.id/files/wisuda/2

018-2-1-54211-613413004-bab1-

08112018040729.pdf. Diakses

pada 22 April 2020.

4. 2020. Bab I Pendahuluan.

http://repository.unair.ac.id/25648/6/13.\%2

a. Banyak tenaga kerja yang tersedia di desa 0 Bab\%201.pdf. Diakses pada 22 April Dilem

2020

b. Pemanfaatan sarana produksi sebagai alat bantu produksi

5. 2007. Peraturan Menteri

Pertanian Nomor

273/Kpts/OT.160/4/2007 Tentang

c. Dukungan dari perangkat atau Pemerintah Pedoman Pembinaan Kelembagaan Desa

Petani. 
dan Gapoktan.

6. 2020. Fungsi Kelompok Tan

Website Desa Pegiringan.

https://pegiringan.desa.id/fungsi-kelompoktani-dan-gapoktan/. Diakses pada 23 April 2020.

7 2020. Indonesia - Survei Sosial

Ekonomi Nasional 2016 Maret (KOR).

https://mikrodata.bps.go.id/mikrodata/index.p hp/catalog/769\%2020.

Diakses pada 22 April 2020.

Deptan. 2007. Pedoman Penumbuhan dan

Pengembangan Kelompok Tani dan

Gabungan Kelompok Tani.

http://perundangan.pertanian.go.id/admin/k_m

entan/SK-273-07.pdf.

Diakses pada 22 April 2020.

Effendi,Midiansyah. 2012. Peranan

Kelompok Tani dalam Mengembangkan

Kemandirian Petani di Kabupaten Tana

Tidung.

https://media.neliti.com/media/publications

1223948-peranan-kelompok-tani-dalampengembangan.pdf. Diakses papa 23 April 2020.

Fatmawati. 2014. Analisis Faktor-faktor yang Mempengaruhi Pendapatan Pedagang Kaki Lima di Pasar Raya Padang.

https://www.neliti.com/id/publications/2 9926/analisis-faktor-faktor-yangmempengaruhi-pendapatan-pedagangkaki-lima-di-pasar. Diakses pada 22 April 2020.

Haka, Maria Goreti dan Taena, Werenfridus. 2017. Analisis Pendapatan Usahatani Cabe Rawit Merah di Desa Tapenpah Kecamatan Insana Kabupaten Timor Tengah Utara. https://media.neliti.com/media/publicati ons/237723-analisis-pendapatanusahatani-cabe-rawit-4f866edd.pdf, Diakses pada 22 April 2020.

Luntungan, Antonius Y . 2012. Analisis Tingkat Pendapatan Usaha Tani Tomat Apel di Kecamatan Tompaso Kabupaten Minahasa.

https://media.neliti.com/media/publications/ 45003-ID-analisis-tingkat-pendapatanusaha-tani-tomat-apel-di-kecamatantompaso-kabupaten.pdf Diakses 23 April 2020.

Masruroh, Ariyani. 2015. Kontribusi Usahatani Tembakau Terhadap Pendapatan Rumah Tangga Di Desa Salamrejo Kecamatan Selopampang Kabupaten Temanggung Jawa Tengah. Skripsi. Fakultas Ekonomi. Universitas Negeri: Yogyakarta.

https://eprints.uny.ac.id/26170/1/SKRIPSI. pdf. Diakses pada 22 April 2020.

Neonbota, Serafina Laka dan Kune, Simon Juan. 2016. Faktor-Faktor Yang Mempengaruhi Usahatani Padi Sawah Di Desa Haekto Kecamatan Noemuti Timur.

https://media.neliti.com/media/publications/ 237705-faktor-faktor-yang-mempengaruhiusahatan-9679d9bd.pdf. Diakses 20 April 2020 .

Onibala, Gabriel; Sondakh, Srie J ; dan Durand, Swenekhe S. 2019. Karakteristik Istri dalam Upaya Meningkatkan Pendapatan Rumah Tangga Nelayan

Tradisional di Desa BulawanInduk Kecamatan Kota bunan kabupate.http://downloads/2813257806-1-

SM\%20(3).pdf\%20n\%20Bolaang\%20Mongon dow\%20Timur. Diakses pada 22 April 2020.

Paulus, Achelien L. Wangke, Welson M. Moniaga, Vicky R.B. Kontribusi Usahatani Kacang Panjang Terhadap Pendapatan Rumah Tangga Petani Di Desa 
Warembungan Kecamatan Pineleng. ASEVolume 11 Nomor 3. September 2015:53-62. https://www.neliti.com/id/publications/3503/k ontribusi-usahatani-kacang-panjang-terhadappendapatan-rumah-tangga-petani-di-d.

Diakses pada 22 April 2020.

Santika, A. 2005. Agribisnis Cabe. Jakarta: Penebar Swadaya.

Setiadi 1999. Cabe Unggul. Jakarta: Swadaya.

Soekartawi. 2011. Ilmu Usahatani, Penerbit Universitas Indonesia (UI Pres).

Sugiyono. 2012. Metode Penelitian Administrasi. Bandung: CV Alfabeta.

Sukananta, I Ketut. 2006. Kontribusi Pendapatan Usahatani Ubi Jalar Terhadap Pendapatan Total Rumah Tangga. E-Jurnal AGRIJATI 3(1).

http://jurnal.unswagati.ac.id/index.php/agrij ati/article/view/42. Diakses tanggal 30

Agustus 2019

Sulandari, S. 2004. Karakterisasi Biologi, Serologi Dan Analisis Sidik Jari DNA Virus Penyebab Penyakit Daun keriting Kuning Cabai. Sekolah Pasca sarjana IPB Disertasi S3. 